\title{
ROLE OF METABOLIC CONTROL ON DIABETIC NEPHROPATHY ${ }^{1}$
}

\author{
Célia Sperandéo Macedo \\ Sonia Maria Capelletti ${ }^{3}$ \\ Maria Cecília Salgado Mercadante ${ }^{3}$ \\ Carlos Roberto Padovani ${ }^{4}$ \\ César Tadeu Spadella
}

Macedo CS, Capelletti SM, Mercadante MCS, Padovan CR, Spadella CT. Role of metabolic control on diabetic nephropathy. Acta Cir Bras [serial online] 2002 Nov-Dec;17(6). Available from URL: http://www.scielo.br/acb.

ABSTRACT - Objective: The aim of this investigation was studying the influence of glucose metabolic control on diabetic nephropathy. The authors observed the effect of acarbose, insulin, and both drugs on the metabolic control and development of mesangial enlargement of kidney glomeruli in alloxan-diabetic rats. Methods: Five groups of Wistar rats were used: normal rats (N), non-treated alloxan-diabetic rats (D), alloxan-diabetic rats treated with acarbose (AD), alloxandiabetic rats treated with insulin (ID), and alloxan-diabetic rats treated with insulin plus acarbose (IAD). The following parameters were evaluated: body weight; water and food intake; diuresis; blood and urine glucose levels; and the kidney lesions: mesangial enlargement and tubule cell vacuolization. Renal lesions were analysed using a semi-quantitative score 1, 3, 6, 9, and 12 months after diabetes induction. Results: Diabetic rats showed a marked increase of glycemia, urinary glucose levels, diuresis, water and food intake, and weight loss, while the treated diabetic rats showed significant decreased levels of these parameters. The most satisfactory metabolic control was that of diabetic rats treated with acarbose + insulin. There was a significant mesangial enlargement in diabetic rats compared to normal rats from the third up to the $12^{\text {th }}$ month after diabetes induction, with a significant difference between the animals treated with acarbose + insulin and non-treated diabetic rats. A difference between the animals treated with acarbose or insulin alone and nontreated diabetics rats was not seen. Conclusions: The authors discuss the results stressing the role of diabetic metabolic control in the prevention of diabetic nephropathy.

KEY WORDS - Experimental diabetes. Alloxan. Diabetic. Nephropathy. Rats.

\section{INTRODUCTION}

Experimental diabetes induced by chemical agents, such as alloxan, causes kidney lesions that are similar to human diabetic nephropathy. ${ }^{(1)}$ In rats, an evident increase of mesangial matrix and thickening of glomerular basement membrane is seen 4-6 months after alloxan injection. ${ }^{(2)}$ Mesangial lesions are at first focal in distribution, becoming generalized and associated with glomerulosclerosis after 12 months of diabetes. Hyaline deposits may be seen peripherally and centrally within glomeruli after 6 months. In the future the lesions may obliterate the glomerulus. Diabetic rats may also have other kidney lesions, such as mesangial

1. Parte da tese apresentada à Faculdade de Medicina de Botucatu - UNESP para obtenção do título de Livre-Docente.

2. Profa. Adjunta do Departamento de Pediatria da Faculdade de Medicina de Botucatu - UNESP.

3. Biólogas do Laboratório de Técnica Cirúrgica e Cirurgia Experimental da Faculdade de Medicina de Botucatu - UNESP.

4. Prof. Titular do Departamento de Bioestatística do Instituto de Biociências do Campus da UNESP de Botucatu.

5. Prof. Adjunto da Disciplina de Gastroenterologia Cirúrgica do Departamento de Cirurgia e Ortopedia da Faculdade de Medicina de Botucatu - UNESP. 
cell proliferation, tubule basement membrane thickening, and glycogen deposits in tubule cells. ${ }^{(3)}$

The glomerular mesangium plays a major role in kidney function loss, with a correlation between mesangial expansion and urinary protein excretion observed in advanced stages of human diabetes. A progressive mesangial expansion has been seen to contribute to the loss of glomerular function. ${ }^{(4)}$

In experimental diabetes, mesangial lesions can be prevented or improved by glycemic control with insulin $^{(5)}$, Langerhans islet transplantation ${ }^{(6)}$ and pancreas transplantation. ${ }^{(7)}$

Acarbose is a competitive inhibitor of the intestinal alpha-glycosidase that can delay absorption of intestinal carbohydrates, causing their malabsorption. ${ }^{(8)}$

Hamada, Iida e Ishimura ${ }^{(9)}$ using acarbose associated with insulin in spontaneous diabetic mice (kk), obtained mesangial lesion improvement. Cohen e Rosemann ${ }^{(10)}$ administered acarbose to Cohen rats with non-insulin-dependent diabetes and, obtained a decrease of glomerulosclerosis. Macedo et al, $1996^{(11)}$ treated alloxan-diabetic rats with acarbose plus insulin and prevented glomerular basement membrane thickening. It is of great interest to evaluate, to what extent, the mesangial lesion can be prevented by diabetes control with these drugs.

\section{METHODS}

\section{Experimental groups}

We used 252 Wistar rats of both sexes approximately 3 months old and weighing 200-300g. They were randomly assigned to the following five experimental groups: group N, 64 non-diabetic control rats; group D, 57 non-treated alloxan-diabetic control rats; group $\mathrm{AD}, 40$ alloxan-diabetic rats treated with $50 \mathrm{mg}$ acarbose (Bayer do Brasil, São Paulo, SP) mixed with $100 \mathrm{~g}$ of Nuvilab CR1 ration (Nuvilab Nutrients Ltda, Curitiba, PR); group ID, 56 alloxan-diabetic rats treated with insulin (Monotard R. Novo Nordisk Farmacêutica do Brasil Ltda, São Paulo, SP), at an initial dose of 18 to $20 \mathrm{U} / \mathrm{kg}$ adjusted to the daily glycosuria and ketonuria; and group IAD, 44 alloxan-diabetic rats treated with insulin plus acarbose.

Each group was subdivided into 5 groups corresponding to sacrifice at $1,3,6,9$, and 12 months after diabetes induction.

The animals with blood glucose levels above $200 \mathrm{mg} / \mathrm{dl}$, urinary glucose above $3,000 \mathrm{mg} / \mathrm{dl}$, and significant increases of water intake and urine output on two successive determinations were included in this experiment.
During all the experiment, all the animals were housed in individual metabolic cages for 24 hours. A predetermined amount of water was supplied for 24 hours and food (standard commercial rat chow; Nuvital Nutrients, Curitiba, PR. Brasil) was supplied for 12 hours. At the end of this procedure, body weight, water and food intake, urine output, urinary glucose, blood sugar, glycosuria, and ketonuria were measured. Plasma and urinary glucose levels were determined by O-toluidine; glycosuria, and ketonuria were evaluated by reagent tapes (gluketur - test, Boehringer Mannhein, RJ. Brasil).

Glucosuria and ketonuria of the animals that received insulin (groups ID and IAD) were determined twice a day ( 8 am and $6 \mathrm{pm})$.

Insulin was subcutaneously administered daily at $6 \mathrm{pm}$. Its dose was adjusted based on the two glycosuria evaluations at 8 am and $6 \mathrm{pm}$. This dose was increased if glycosuria was positive at the two evaluations, maintained if glycosuria was negative at 8 am and positive at $6 \mathrm{pm}$, and discontinued if glycosuria was negative at the two evaluations.

\section{Morphological studies of kidney lesions}

Kidney tissue from the sacrificed animals after diabetes induction was fixed in $10 \%$ buffered formalin, embedded in paraffin, cut into $4 \mathrm{~m}$-thick sections, stained with hematoxilin and eosin, Masson's trichrome, and periodic acid-Schiff stains. The sections were coded to mask their identification by the examiner. Fifty glomeruli and the related tubules from each kidney were examined by light microscopy without knowledge of the groups from which the tissue had been obtained. The following two lesions were scored on a scale of 0 (absent), 1(mild), 2 (moderate), 3 (severe) mesangial enlargement (ME) and vacuolization of the tubules (Armanni-Ebstein lesions - AE). The scores for each lesion were expressed as a total count per rat by adding the individual scores for each glomerulus and related tubules.

\section{Statistical analysis}

Clinical and laboratory parameters were analyzed using ANOVA. This was complemented by the multiple Tuckey's comparison. ${ }^{(12)}$ Kruskal-Wallis test was used for mesangial enlargement and tubular lesion for the comparison of the groups and sacrifice times. ${ }^{(13)}$

\section{RESULTS}

\section{Clinical and laboratory}

The body weight of D rats was statistically lower than normal rats $(\mathrm{N})$. The $\mathrm{AD}$ rats showed similar 
weight to D rats; ID and IAD rats showed higher weight than $\mathrm{D}$ and $\mathrm{AD}$ rats. Water intake of diabetic rats (D) was about $98.4 \mathrm{ml} / 24$ hours and normal rats (N) about $30 \mathrm{ml} / 24 \mathrm{~h}$. This parameters in groups ID and IAD were statistically lower than that of group D from the third to the $12^{\text {th }}$ month after diabetes induction. Urine output of group D rats was about $60 \mathrm{ml} / 24 \mathrm{~h}$ and of $\mathrm{N}$ rats about $10.0 \mathrm{ml} / 24 \mathrm{~h}$. The ID and IAD animals showed urine output compatible with metabolic control of diabetes being lower than group $\mathrm{D}$ from the third to the $12^{\text {th }}$ month after diabetes induction (Figure 1).

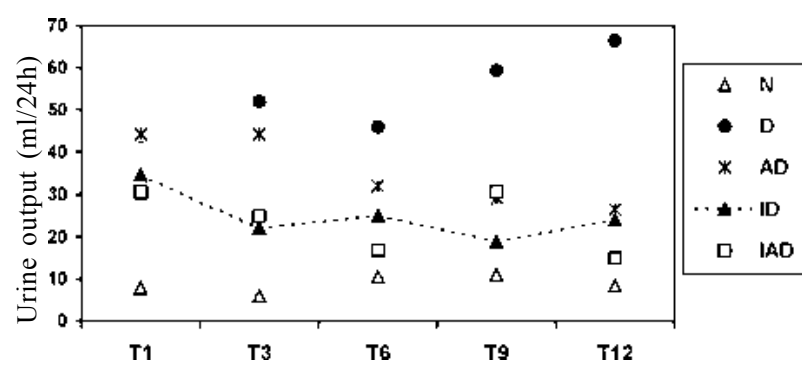

FIGURE 1 - Urine output: means of the groups at each sacrifice time.

\section{Renal lesions}

A gradual mesangial enlargement (ME) was seen in the $\mathrm{D}$ rats from the $3^{\text {rd }}$ to the $12^{\text {th }}$ month after diabetes induction (Table 1). The IAD rats showed similar ME to that of $\mathrm{N}$ rats from the $1^{\text {st }}$ to the $12^{\text {th }}$ month after diabetes induction.
Diabetic animals showed blood sugar levels above $200 \mathrm{mg} / \mathrm{dl}$, urinary glucose above $3,000 \mathrm{mg} / \mathrm{dl}$, glycosuria, and occasionally ketonuria. Severe diabetes was evident in these animals when compared to nondiabetic control rats $(\mathrm{N})$.

The comparison between the treated groups and diabetic groups without treatment (D), showed that groups $\mathrm{AD}$, ID and IAD had lower glycemia levels than group D; and the lowest values were of IAD rats (Figure 2). Groups ID and IAD showed statistically lower urinary glucose levels than group D 3 months after diabetes induction until the $12^{\text {th }}$ month. The lowest values were also of the IAD rats.

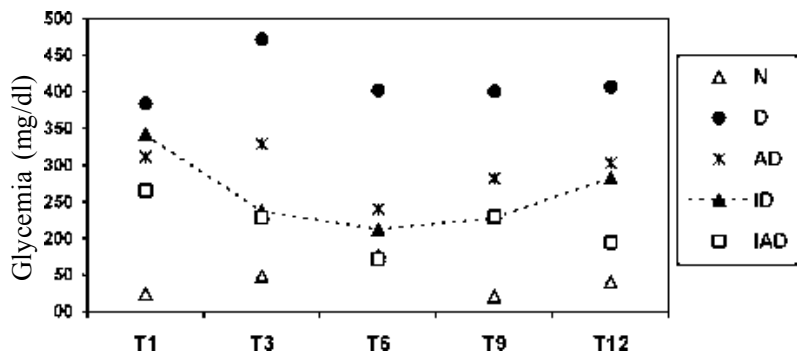

FIGURE. 2 - Glycemia: means of the groups at each sacrifice time.

Table 2 shows the medians of Armanni - Ebstein lesions, consisting of renal tubule cell vacuolization and distension due to glycogen accumulation.

Renal glomeruli and tubules of N, D, ID, AD, and IAD rats are shown in Figures 3 and 4.

TABLE 1 - Mesangial enlargement - Median and total semirange, results of the statistical test of the five groups, and sacrifice times.

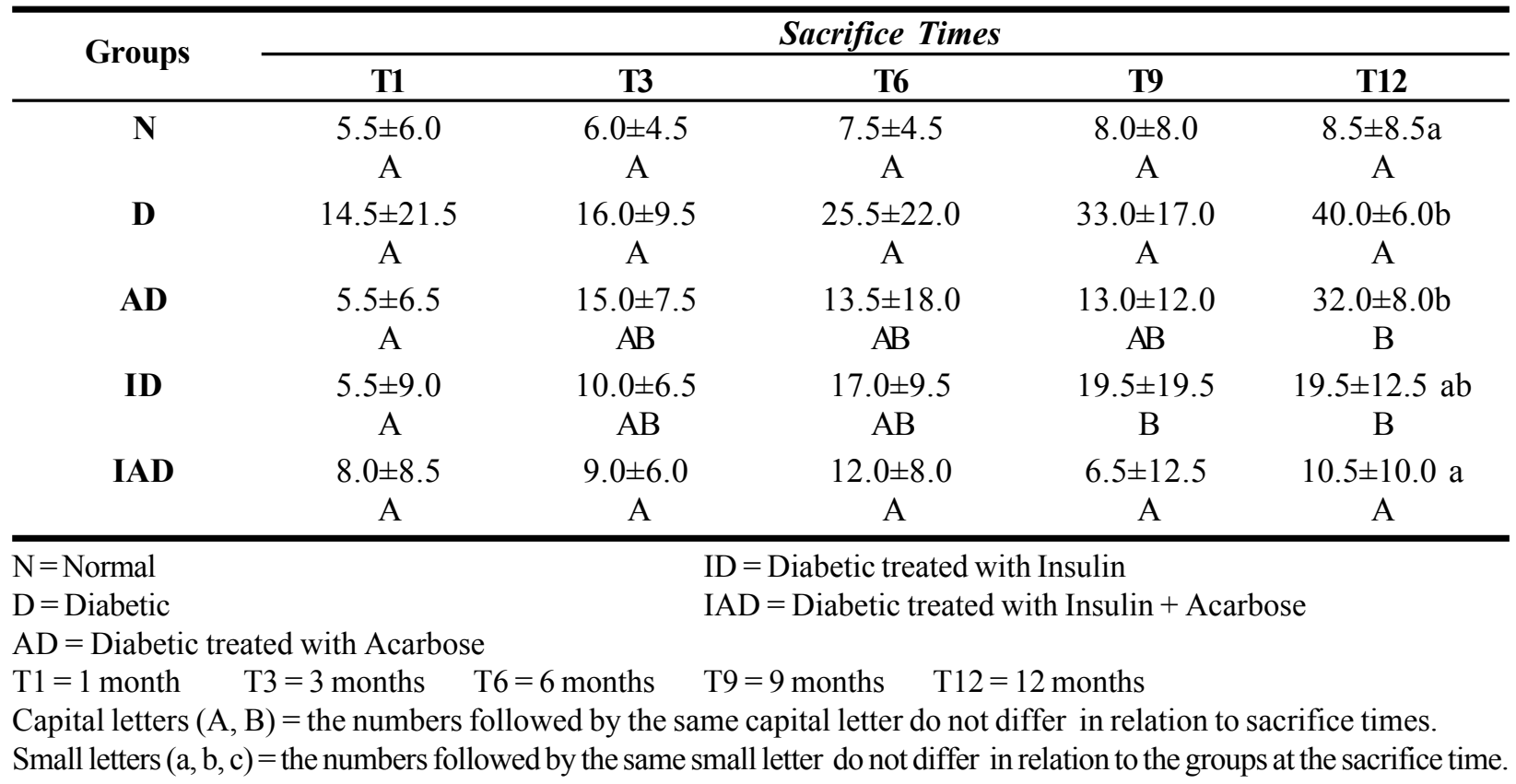


TABLE 2 - Armanni-Ebstein lesions in tubules - Median and total semirange, results of the statistical test of the five groups, and sacrifice times.

\begin{tabular}{|c|c|c|c|c|c|}
\hline \multirow{2}{*}{ Grupos } & \multicolumn{5}{|c|}{ Sacrifice Times } \\
\hline & T1 & T3 & T6 & T9 & T12 \\
\hline \multirow[t]{2}{*}{$\mathbf{N}$} & $0 \pm 0 \mathrm{a}$ & $0 \pm 0 \mathrm{a}$ & $0 \pm 0 \mathrm{a}$ & $0 \pm 0 \mathrm{a}$ & $0 \pm 0.5 \mathrm{a}$ \\
\hline & A & A & $\mathrm{A}$ & A & A \\
\hline \multirow[t]{2}{*}{ D } & $2.0 \pm 1.0 \mathrm{~b}$ & $3.0 \pm 1.5 \mathrm{~b}$ & $3.0 \pm 0.5 \mathrm{~b}$ & $3.0 \pm 0.5 \mathrm{~b}$ & $3.0 \pm 0.5 \mathrm{~b}$ \\
\hline & A & $\mathrm{A}$ & $\mathrm{A}$ & $\mathrm{A}$ & A \\
\hline \multirow[t]{2}{*}{ AD } & $3.0 \pm 1.0 \mathrm{~b}$ & $3.0 \pm 0.5 b$ & $2.5 \pm 1.0 \mathrm{~b}$ & $2.0 \pm 1.5 \mathrm{~b}$ & $2.5 \pm 1.0 \mathrm{~b}$ \\
\hline & A & A & A & A & $\mathrm{A}$ \\
\hline \multirow[t]{2}{*}{ ID } & $0 \pm 0 \mathrm{a}$ & $0 \pm 0.5 \mathrm{a}$ & $0 \pm 0.5 \mathrm{a}$ & $0 \pm 1.0 \mathrm{a}$ & $0 \pm 1.0 \mathrm{a}$ \\
\hline & $\mathrm{A}$ & $\mathrm{A}$ & $\mathrm{A}$ & A & A \\
\hline \multirow[t]{2}{*}{ IAD } & $0 \pm 1.5 \mathrm{a}$ & $0 \pm 1.0 \mathrm{a}$ & $0 \pm 1.0 \mathrm{a}$ & $0 \pm 0 \mathrm{a}$ & $0 \pm 1.0 \mathrm{a}$ \\
\hline & $\mathrm{A}$ & $\mathrm{A}$ & $\mathrm{A}$ & A & $\mathrm{A}$ \\
\hline
\end{tabular}

$\mathrm{N}=$ Normal

ID $=$ Diabetic treated with Insulin

$\mathrm{D}=$ Diabetic

$\mathrm{IAD}=$ Diabetic treated with Insulin + Acarbose

$\mathrm{AD}=$ Diabetic treated with Acarbose

$\mathrm{T} 1=1$ month $\quad \mathrm{T} 3=3$ months $\quad \mathrm{T} 6=6$ months $\quad \mathrm{T} 9=9$ months $\quad \mathrm{T} 12=12$ months

Capital letters $(A)=$ the numbers followed by the same capital letter do not differ in relation to sacrifice times.

Small letters $(a, b)=$ the numbers followed by the same small letter do not differ in relation to the groups at the sacrifice time.


FIGURE 3 - Renal glomeruli and tubules of N, D, ID, AD, and IAD rats sacrificed at 9 and 12 months after diabetes induction. A - Glomerulus of a D rat after 12 months of diabetes induction, showing a bulk of hyaline material in a segment of the glomerular tuft (PAS, 200x).

$\mathrm{B}$ - Glomeruli of a D rat after 12 months of diabetes induction, with evident mesangial enlargement in both glomeruli (PAS, 200x). $\mathrm{C}$-Glomerulus of a D rat after 12 months of diabetes induction, with hyaline material in a segment of the glomerular tuft (HE, 200x). D - Glomerulus of an IAD rat treated for 9 months. Mesangium with a normal aspect (Masson's Trichrome, 200x) 

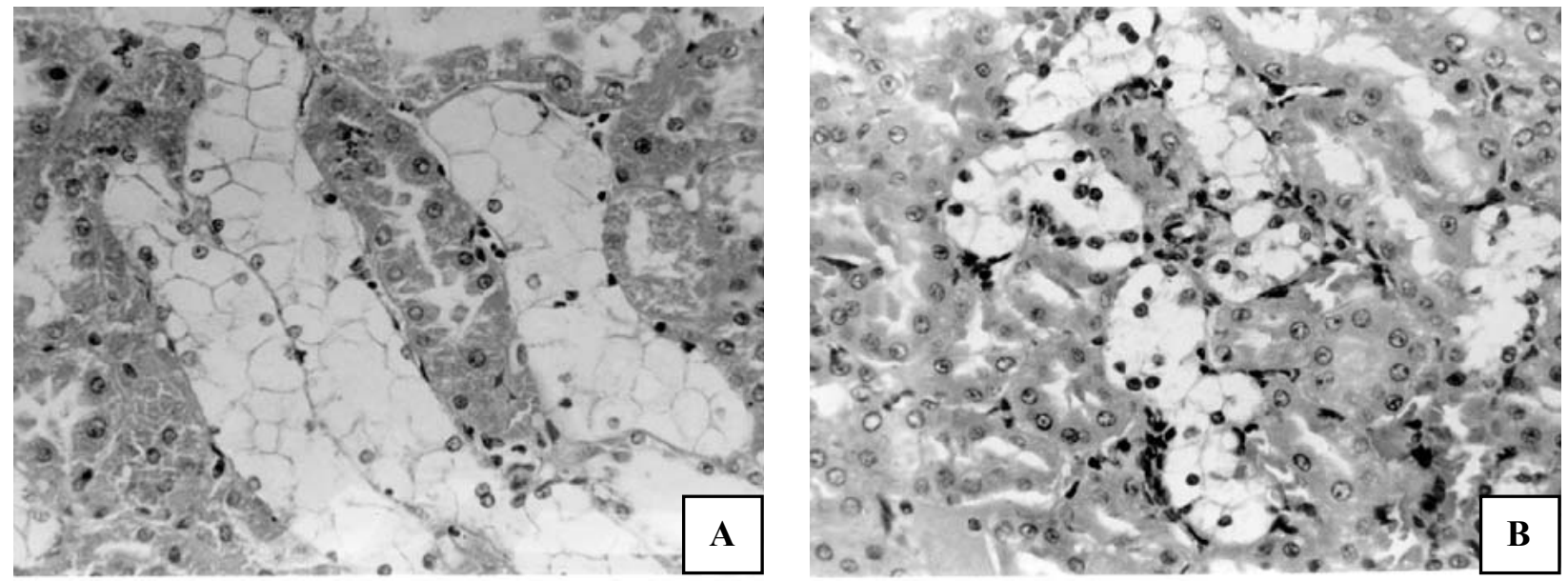

FIGURE 4 - Tubules of D and AD rats sacrificed at 9 and 12 months after diabetes induction.

A - Armanni - Ebstein lesions with renal tubules showing severe glycogenic vacuolization (clear cells) in D rats.

B - Armanni - Ebstein lesions with renal tubules showing glycogenic vacuolization in AD rats (H\&E, 200x)

\section{DISCUSSION}

Mesangial hypertrophy has been observed in diabetic rats by light and electron microscopy between 6 and 12 months after diabetes induction ${ }^{(1,2,14)}$.

In our study mesangial enlargement starting in the $3^{\text {rd }}$ month was detected in alloxan-diabetic rats (D) in relation to normal rats $(\mathrm{N})$; this increase was observed from the 6th to the 12th months.

The IAD rats differed from $\mathrm{N}$ rats in the third and sixth months; in all other times, IAD rats did not differ from $\mathrm{N}$ rats, which is in agreement with the prevention of mesangial enlargement in this group. Mesangial enlargement was partially prevented in AD and ID rats. These results are also in agreement with the best diabetes metabolic control shown by the IAD rats. Despite good metabolic control observed in the IAD animals, they presented lower body weight than ID groups, probably because of diarrhea episodes caused by acarbose, one of the side effects of this drug.

The best diabetes metabolic control prevented mesangial increase, as observed by Rash, using insulin for 6 months in streptozotocin-diabetic rats. ${ }^{(15)}$

Lee et al. (1982) found a significant decrease of mesangial enlargement using acarbose (40mg: $100 \mathrm{~g}$ of mice chow) for 10 weeks in genetically diabetic mice. ${ }^{(16)}$ Hamada et al. (1989) reported a similar finding by administering acarbose to spontaneous diabetic $\mathrm{kk}$ mice and observed a glycogen decrease in tubule cells..$^{(9)}$

Acarbose is a pseudotetrasaccharide that is not absorbed to a significant extent and is most effective when given immediately before or with a meal containing carbohydrates. Its glucose lowering effect does not extend beyond the immediate postprandial period of 1 to 2 hours. The major effect of acarbose is on postprandial hyperglycemia, with a final effect on glycosilated hemoglobin.

In streptozotocin-diabetic rats treated with acarbose for 8 weeks, lower levels of glycosilated hemoglobin, urine output, water intake, blood and urinary glucose were seen. ${ }^{(17)}$

In rats with non-insulin-dependent diabetes, the treatment with acarbose accounted for a decrease in glomerulosclerosis and a significantly longevity ${ }^{(10)}$; in alloxan-diabetic rats treated with acarbose plus insulin a correlation was found between better metabolic control and a decrease of retinal alterations. ${ }^{(18)}$

The IAD rats showed the best results in urinary output, water intake, blood and urinary glucose, suggesting a synergistic effect of insulin and acarbose. This finding may have clinical applications in insulindependent diabetes mellitus.

The mesangium is an intracapillary network of mesangial cells and matrix that is contiguous with the circulation through a layer of endothelial cells with fenestrae. The advanced glycation end products (AGE) sieved through the mesangium and mesangial receptors for these products in rats play an important role in mesangial matrix increase. ${ }^{(19)}$

Many other pathogenic factors are involved in mesangial matrix increase. Sharma et al. (1996), using antibody to TGF-b, reported a prevention of glomerular hypertrophy and partial normalization of matrix synthesis $^{(20)}$. In fact, enhanced renal expression of TGF$\mathrm{b}$ protein and mRNA has been reported in a range of glomerular diseases. ${ }^{(21)}$ According to these authors, hyperglycemia leads to hyperfiltration, and mesangial stretch serves as a signal for increased production of TGF-b by mesangial cells; this cytokine being the causative factor of increased mesangial matrix 
synthesis. In addition to matrix synthesis increase, diabetic rats showed a decrease of metalloproteinase activity and smaller degradation rate of extracellular matrix compounds. ${ }^{(22)}$

In diabetes, many mechanisms, such as cellular, hemodynamic, and increase of formation of advanced glycation end products ${ }^{(23)}$ caused by hyperglycemia account for mesangial increase. Then, the use of drugs for glycemia control plays a major role in the prevention of mesangial expansion, and as a consequence, renal dysfunction.

In this research, we observed an attenuated mesangial expansion by long-term treatment with drugs that contributed to a relative metabolic control of diabetic state in alloxan-diabetic rats. In conclusion, these data show the efficacy of insulin-acarbose treatment in mesangial enlargement in diabetic rats.

\section{REFERENCES}

1. Mauer SM, Steffes MW, Connett J, Najarian JS, Sutherland DE, Barbosa,J. The development of lesions in the glomerular basement membrane and mesangium after transplantation of normal kidney to diabetic patients. Diabetes 1983; 32: 948-52.

2. Hagg E. Renal lesions in rats with long-term alloxan diabetes. Acta Pathol Microbiol Scand A 1974; 82: 199-210.

3. Evans AP, Mong SA, Connors BA, Aronoff GR, Luft FC. The effect of alloxan, and alloxan-induced diabetes on the kidney. Anat Rec 1984; 208: 33-47.

4. Mauer SM. Structural-functional correlation of diabetic nephropathy. Kidney Int 1994; 45: 612-22.

5. Rasch R. Prevention of diabetic glomerulopathy in streptozotocin diabetic rats by insulin treatment: the mesangial regions. Diabetologia 1979; 17: 243-8.

6. Wehner H, Kosters W, Strauch M, Staudenmeir M. Effect of islet transplantation on the glomerular changes in streptozotocin diabetic rats. Virchows Arch A Pathol Anat Histol 1980; 388: 137-54.

7. Orloff MJ, Macedo AR, Macedo CS, Yamanaka N, Huang YT, Huang DG, Leng XS, Stilber A, Kreidieh I, Greenleaf G. Prevention, stabilization and reversal of the metabolic disorders and secondary complications of diabetes by pancreas transplantation. Transplant Proc 1988; 20 (suppl. 1):868-73.
8. Puls W, Keup U, Krause HP, Thomas HF. Glucosidase innibition, a new approach to the treatmente of diabetes obesity and hyperlipo proteina. Natur wissenchaften 1977; 64: 536-7.

9. Hamada H, Iida R, Ishimura. K. Effect of acarbose on diabetes in KK mice. Yakuri to Chiryo 1989; 17: 17-25.

10. Cohen AM, Rosenmann E. Acarbose treatment and diabetic nephropathy in the Cohen diabetic rat. Horm Metab Res 1990; 23: 511-5.

11. Macedo CS, Silva MD, Spadella CT, Breim LC, Capeletiti S, Mercadante MCS, Hernandes D, Macedo AR. Effect of longterm treatment with insulin and/or acarbose on glomerular basement membrane thickening in alloxan-diabetic rats. Braz J Med Res 1996; 29: 1229-35.

12. Montgomery DC. Design and analysis of experiments 3ed New York: John Wiley; 1991.

13. Siegel S, Castellan Jr. Ni. Non parametric statistics for the behavioral sciences. 2ed New York: McGraw-Hill; 1988.

14. Anjo A, Counturier E. Mesangial changes of the renal glomerulus in long-term diabetic rats. Pathol Eur 1975; 10: 21-7.

15. Rasch R. Studies on the prevention of glomerulopathy in diabetic rats. Acta Endocrinol Suppl 1981; 242: 43-4.

16. Lee SM. The effect of chronic a-glycosidase inhibition on diabetes nephropathy in the $\mathrm{db} / \mathrm{db}$ mouse. Diabetes 1982; 31: 249-53.

17. Katovich MJ, Meldrum MJ, Vasselli. JR. Beneficial effects of dietary acarbose in the Streptozotocin Induced diabetic rat. Metabolism 1991; 40: 1275-82.

18. Schellini SA, Gregorio EA, Spadella CT, Machado JLM, Moraes Silva MA. Muller cells and diabetic retinopathy. Braz J Med Res 1995; 28: 977-80.

19. Skolnik EY, Yang Z, Makita Z, Radoff S, Kirstein M, Vlassara N. Human and rat mesangial cell receptors for glucose-modified proteins: potential role in kidney tissue remodeling and diabetic nephropathy. J Exp Med 1991; 174: 931-9.

20. Sharma K, Jin Y, Guo J, Ziyadeh FN. Neutralization of TGF-b antibody attenuates kidney hyperthrophy and the enhanced extracellular matrix gene expression in STZ induced diabetic mice. Diabetes 1996; 45: 522-30.

21. Border WA, Yamamoto T, Noble NA. Transforming growth factor b in diabetic nephropathy. Diabetes Metab Rev 1996; 12: $309-39$.

22. Reckelhoff JF, Tygart VL, Mitias MM, Walcott JL. Stz-induced diabetes results in decreased activity of glomerular cathepsin and metallo protease in rats. Diabetes 1993; 42: 1425-32.

23 Nishikawa T, Edelstein D, Brownlee M. The missing link a single unifying mechanism for diabetic complications Kidney Int 2000; 58 (suppl 77): S26-30. 
Macedo CS, Capelletti SM, Mercadante MCS, Padovan CR, Spadella CT. O papel do controle metabólico sobre a nefropatia diabética. Acta Cir Bras [serial online] 2002 Nov-Dez;17(6). Disponível em URL: http://www.scielo.br/acb.

RESUMO - Objetivo: Os autores relatam a influência do controle metabólico do diabetes, experimentalmente induzido no rato, sobre a nefropatia diabética. Eles observaram o efeito da insulina, da acarbose, um inibidor da glicosidase, e de dois agentes combinados sobre o controle metabólico e o desenvolvimento da expansão mesangial de glomérulos renais, no diabetes induzido pela aloxana no rato. Métodos: Usando 5 grupos de ratos Wistar assim definidos: $\operatorname{Normal}(\mathrm{N})$, diabéticos não-tratados (D), diabéticos tratados com acarbose (AD); diabéticos tratados com insulina (ID) e diabéticos tratados com insulina associada à acarbose (IAD) foram avaliados os seguintes parâmetros: peso corporal, ingestão alimentar, ingestão hídrica, diurese, níveis de glicose sanguínea e urinária e as lesões renais: alargamento mesangial e vacuolização de células tubulares, usando contagem semi-quantitativa 1, 3, 6, 9 e 12 meses após a indução do diabetes. Resultados: Houve acentuado aumento da glicemia, dos níveis de glicose na urina, da diurese, da ingestão hídrica e alimentar, e progressiva perda de peso nos ratos diabéticos, enquanto que os ratos diabéticos tratados exibiram melhora significativa destes parâmetros, sendo os ratos tratados com insulina + acarbose os que apresentaram controle metabólico mais satisfatório. Houve um significativo alargamento mesangial nos ratos diabéticos quando comparado ao observado nos ratos normais, desde o $3^{\circ}$ até o $12^{\circ}$ mês após a indução do diabetes, sendo observada diferença significativa entre os animais tratados com acarbose + insulina e os ratos diabéticos não-tratados. Não houve diferença significativa entre os animais tratados somente com acarbose ou com insulina quando comparados com ratos diabéticos não-tratados. Conclusão: Os autores discutem os resultados abordando o papel do controle metabólico do diabetes na prevenção da nefropatia diabética.

DESCRITORES - Diabetes experimental. Aloxana. Nefropatia diabética. Ratos.

Conflito de interesse: nenhum

Fonte de financiamento: FAPESP

Address for correspondence:

Célia Sperandéo Macedo

Universidade Estadual Paulista - Faculdade de Medicina de Botucatu

Departamento de Pediatria

18618-970 Botucatu - SP

Fax: (14) 6802-6274

Data do recebimento: $23 / 08 / 2002$

Data da revisão: 12/09/2002

Data da aprovação: 03/10/2002

\section{SOBRADPEC - HOME PAGE}

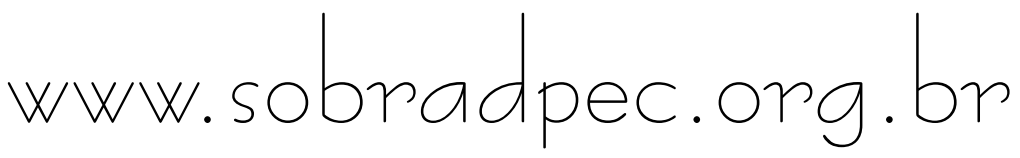

